\title{
UJI KECERNAAN BAHAN KERING DAN BAHAN ORGANIK PAKAN KOMPLIT HASIL SAMPING UBI KAYU KLON® PADA DOMBA JANTAN LOKAL LEPAS SAPIH
}

\author{
(Analyze The Digestibility of Dry Matter And Organic Matter Cassava Clones ${ }^{\circledR}$ Byproducts \\ on The Weaning Local Male Sheep)
}

\author{
Berry Okta Libra ${ }^{1}$, Tri Hesti Wahyuni' ${ }^{2}$ dan Edhy Mirwandhono ${ }^{2}$ \\ 1. Mahasiswa Program Studi Peternakan Fakultas Pertanian Universitas Sumatera Utara' \\ 2. Staf Pengajar Program Studi Peternakan Fakultas Pertanian Universitas Sumatera Utara
}

\begin{abstract}
This study aims to analyze the digestibility of dry matter and organic matter cassava clones by-products on the weaning local male sheep. The experiment was conducted at Laboratory of Animal Biology, Faculty of Agriculture Livestock Studies Program University of Sumatra Utara in September to December 2013. The design used in this research is completely randomized design (CRD) with 3 treatments and 4 repications. The design consist of P0: ( $100 \%$ grass ), P1 ( $50 \%$ grass and $50 \%$ cassava by product) and ( P2 $100 \%$ cassava by product ). The results showed the average digestibility dry matter 47,00(\%), 52,43(\%) and 54,65(\%) respectively. Organic matter were 50,19 (\%), 52,74 (\%) and 54,81(\%) respectively. Statistical test results showed that feeding cassava were very significant effect on the digestibility of dry matter and organic matter.The conclusions of this study the cassava by product digestibility of dry matter and organic matter better than digestibility of dry matter and organic matter of grass, so cassava by products can be use as an alternative feed.
\end{abstract}

Keywords : Cassava, By product, Local sheep male .

\begin{abstract}
ABSTRAK
Penelitian ini bertujuan untuk menganalisis kecernaan bahan kering dan bahan organik hasil samping ubi kayu klon yang pada domba jantan lokal lepas sapih. Penelitian dilaksanakan di Laboratorium Biologi Ternak Program Studi Peternakan Fakultas Pertanian Univesitas Sumatera Utara pada bulan September sampai Desember 2013.Rancangan yang digunakan dalam penelitian ini adalah rancangan acak lengkap (RAL) dengan 3 perlakuan 4 ulangan. Perlakuan ini terdiri atas P0: (rumput hijauan $100 \%$ ); P1( hijauan 50\% dan 50\% pakan komplit); (P2 pakan komplit 100\%).Hasil penelitian menunjukkan rataan kecernaan bahan kering (\%) adalah 47,00, 52,43 dan 54,65. Rataan kecernaan bahan organik $(\%)$ adalah $50,19,52,74,54,81$. Uji statistik menunjukan bahwa pemberian pakan hasil samping ubi kayu berpengaruh sangat nyata terhadap kecernaan bahan kering dan bahan organik.Kesimpulan dari hasil penelitian menunjukkan bahwa kecernaan bahan kering dan bahan organik pakan hasil samping ubi kayu lebih baik dari pada kecernaan bahan kering dan bahan organik pakan rumput, sehingga pakan hasil samping ubi kayu klon dapat digunakan sebagai pakan pengganti.
\end{abstract}

Kata kunci : Ubi kayu klon, Hasil samping, Domba lokal 


\section{PENDAHULUAN}

Pada ternak ruminansia, hijauan merupakan bahan pakan utama. Salah satu yang menjadi kendala adalah tidak tersedianya hijauan yang berkualitas pada sepanjang tahun. Pada musim kemarau, hijauan menjadi sangat sulit diperoleh dan harganya pun mahal sehingga pemeliharaan ternak menjadi tidak layak lagi secara ekonomi. Sedangkan pengembangan produksi hijauan terbentur pada masalah lahan, dimana penggunaan lahan semakin meningkat untuk keperluan tempat pemukiman dan keperluan lahan untuk pangan. Pakan merupakan salah satu faktor utama yang mempengaruhi sukses tidaknya usaha peternakan domba. Salah satu upaya dalam pengadaan pakan bagi ternak adalah memanfaatkan seoptimal mungkin lahan serta pemanfaatan hasil samping komoditi pertanian. Hal ini tidak terlepas dari semakin sulitnya memperoleh hijauan pakan ternak karena semakin banyaknya usaha peternakan domba yang berdiri.

Saat ini dibutuhkan suatu pemecahan masalah pakan untuk ternak domba.Salah satu faktor pembatas laju peningkatan usaha peternakan yaitu ketersediaan pakan dan merupakan faktor pembatas terbesar adalah pembiayaan produksi peternakan. Untuk mengatasi masalah tersebut alternatif pilihan adalah pemanfaatan hasil samping pertanian yang salah satunya adalah ubi kayu. Indonesia merupakan negara agraris yang memiliki produk samping pertanian yang cukup banyak dan tersedia sepanjang tahun.Namun, pemanfaatan produk samping pertanian tersebut untuk bahan pakan ternak ruminansia belum maksimal. Penyebabnya adalah pada ubi kayu terdapat zat anti nutrisi yaitu $\mathrm{HCN}$, untuk dapat digunakan perlu dilakukan pengolahan untuk mengurangi/menghilangkan kandungan HCNnya, yaitu dengan cara mengeringkan atau menjemur daun ubi kayu klon tersebut.

Pemanfaatan limbah daun ubi kayu sebagai sumber bahan pakan ternak masih sangat sedikit sedangkan perkembangan peternakan terus meningkat dengan laju pertumbuhan 12,9\%/tahun. Untuk itu produksi hasil samping tanaman dan produksi ubi meningkat. Hasil samping tersebut dapat dimanfaatkan sebagai pakan pengganti hijauan yang ketersediaanya semakin terbatas. Dengan demikian,pemanfaatan limbah tanaman pangan merupakan salah satu solusi untuk mengembangkannya. Sehubungan dengan letak geografis Sumatera Utara yang 
cukup strategis telah membuka peluang untuk masuknya produk peternakan diantaranya daging baik dari beberapa propinsi lain maupun dari luar negeri.

Hal tersebut dimungkinkan karena Sumatera Utara harus memenuhi permintaan lokal yang sampai saat ini masih belum dapat dipenuhi sendiri. Selain itu dengan masuknya era pasar bebas telah membuka peluang masuknya produk peternakan asing baik yang legal maupun ilegal. Data dari dinas peternakan propinsi menunjukkan bahwa saat Sumatera Utara masih kekurangan daging setara dengan 10.000 ekor sapi setiap tahunnya.

Kondisi tersebut dapat menjadikan dorongan bagi Sumatera Utara untuk dapat mengembangkan industri peternakan dengan menekankan potensi lokal serta mendorong partisipasi penanam modal setempat.

Atas dasar pemikiran inilah perlu diadakan suatu penelitian tentang pemanfaatan hasil samping ubi kayu klon sebagai pakan ternak yang diharapkan dapat meningkatkan Kecernaan BK dan Kecernaan BO pada ternak domba jantan lokal lepas sapih.

\section{BAHAN DAN METODE PENELITIAN}

\section{Lokasi dan Waktu Penelitian}

Penelitian dilaksanakan di Laboratorium Biologi Ternak Program Studi Peternakan, Fakultas Pertanian, Universitas Sumatera Utara. Penelitian berlangsung selama 3 bulan di mulai dari September 2013 sampai Desember 2013.

\section{Bahan dan Alat}

Adapun jumlah domba yang digunakan dalam penelitian ini adalah sebanyak 12 ekor domba dengan kisaran bobot badan awal $(7,75 \pm 1.75 \mathrm{~kg})$, ransum terdiri dari kulit umbi ubi kayu, daun ubi kayu beserta batang muda ubi kayu, BIS, garam,molases, air minum diberikan secara adlibitum, obat-obatan seperti obat cacing (kalbazen), anti bloat (kembung) dan vitamin.

\section{Alat}

Kandang individual 12 unit beserta perlengkapannya, tempat pakan dan minumnya masing-masing 12 buah, timbangan bobot hidup dan bobot non karkas berkapasitas $50 \mathrm{~kg}$ dengan kepekaan $50 \mathrm{~g}$, timbangan berkapasitas $2 \mathrm{~kg}$ dengan kepekaan $10 \mathrm{~g}$ untuk menimbang pakan. Mesin penggiling pakan (chopper), alat pembersih kandang seperti sapu lidi, dan sekop, 
thermometer untuk mengetahui suhu kandang, pisau dan cutter, ember, plastik, alat tulis, buku data dan kalkulator.

\section{Metode penelitian}

Adapun metode yang digunakan adalah rancangan acak lengkap (RAL) dengan 3 perlakuan 4 ulangan, yaitu:

P0: Pemberian pakan hijauan $100 \%$

P1: Pemberian pakan komplit 50\% + hijauan $50 \%$

P2: Pemberian pakan komplit $100 \%$

Tabel 1. Susunan Pakan Komplit

\begin{tabular}{lllll}
\hline Bahan Pakan & Jumlah & PK & SK & TDN \\
\hline Daun Ubi & 50.00 & 8.56 & 9.73 & 38.25 \\
Batang Muda & 20.00 & 1.23 & 7.59 & 12.95 \\
Onggok & 5.00 & 0.10 & 0.82 & 3.85 \\
BIS & 20.00 & 3.08 & 2.10 & 16.20 \\
Molases & 3.00 & 0.02 & 0.01 & 2.43 \\
Urea & 1.00 & 2.02 & 0.00 & 0.00 \\
Garam & 0.50 & 0.00 & 0.00 & 0.00 \\
Mineral & 0.50 & 0.00 & 0.00 & 0.00 \\
\hline Jumlah & 100.00 & 15.02 & 20.25 & 73.68
\end{tabular}

Sumber: Laboratorium Ilmu Makanan Ternak, Program Studi Peternakan FP USU Medan (2009).

\section{Parameter Penelitian}

\section{Konsumsi (Bahan Kering dan Bahan Organik)}

Konsumsi bahan kering dan bahan organik diukur dengan mengalikan konsumsi ransum dengan kandungan bahan kering dan bahan organik yang diperoleh dari data analisis di laboratorium.Periode pengukuran dilakukan selama satu minggu (Parakkasi,1995). 


\section{Kecernaan Bahan Kering (KcBK)}

Kecernaan bahan kering didapatkan dengan cara mengurangi bahan kering konsumsi dengan bahan kering feses lalu dibagi dengan bahan kering konsumsi yang kemudian dikali seratus persen (McDonald et al.,1995).

Koefisien cerna bahan kering dihitung dengan menggunakan rumus:

$$
\mathrm{KcBK}=\frac{(\text { Konsumsi BK }- \text { Pengeluaran BK })}{\text { Konsumsi BK }} \times 100 \%
$$

Bahan kering konsumsi didasarkan pada hasil analisis proksimat dan bahan kering feses diukur dari hasil rata-rata pengukuran bahan kering feses selama tujuh hari terakhir setiap periode penelitian.

\section{Kecernaan Bahan Organik (KcBO)}

Kecernaan bahan organik didapatkan dengan cara mengurangi bahan organik konsumsi dengan bahan organik feses lalu dibagi dengan bahan organik konsumsi yang kemudian dikali seratus persen.Koefisien cerna bahan organik dihitung dengan menggunakan rumus:

$$
\mathrm{KcBO}=\frac{(\text { Konsumsi BO }- \text { Pengeluaran BO })}{\text { Konsumsi }} \times 100 \%
$$

Bahan organik konsumsi didasarkan pada hasil analisis proksimat dan bahan organik feses diukur dari hasil rata-rata pengukuran bahan organik feses selama tujuh hari terakhir setiap periode penelitian (Haris, 1970).

\section{HASIL DAN PEMBAHASAN}

Rekapitulasi rataan hasil penelitian konsumsi bahan kering, konsumsi bahan organik, kecernaan bahan kering dan kecernaan bahan organik hasil penelitian dapat dilihat pada Tabel 2 Berdasarkan Tabel 2 dapat dilihat konsumsi bahan kering pakan yang tertinggi adalah terdapat pada perlakuan P0 (hijauan 100\%) sebesar 477,34 g/ekor/hari dan yang terendah terdapat pada perlakuan P2 (pelet 100\%), sebesar 256,77 g/ekor/hari. Konsumsi bahan organik yang tertinggi terdapat pada perlakuan P1 sebesar 302, 55 g/ekor/hari dan yang terendah pada perlakuan P2 sebesar 182, 72 g/ekor/hari. Pada tabel 2 menunjukkan bahwa kecernaan bahan kering tertinggi 
terdapat pada P2 sebesar 54,65\% sedangkan kecernaan terendah terdapat pada perlakuan P0 sebesar 47,00\% dan kecernaan bahan organik tertinggi terdapat pada perlakuan P2 sebesar $54,81 \%$ sedangkan kecernaan terendah terdapat pada P0 sebesar 50,19\%.

Tabel 2. Rekapitulasi hasil penelitian

\begin{tabular}{lcccc}
\hline Perlakuan & $\begin{array}{c}\text { Konsumsi BK } \\
\text { (g/ekor/hari })\end{array}$ & $\begin{array}{c}\text { Konsumsi BO } \\
\text { (g/ekor/hari) }\end{array}$ & $\begin{array}{c}\text { Kecernaan BK } \\
(\%)\end{array}$ & $\begin{array}{c}\text { Kecernaan BO } \\
(\%)\end{array}$ \\
\hline P0 & $477,34 \pm 15,13$ & $302,55 \pm 3,99$ & $3,34^{\mathrm{C}} \pm 47,00$ & $0,22^{\mathrm{B}} \pm 50,19$ \\
P1 & $318,10 \pm 13,50$ & $219,61 \pm 6,84$ & $1,38^{\mathrm{B}} \pm 52,43$ & $2,39^{\mathrm{A}} \pm 52,74$ \\
P2 & $256,77 \pm 3,43$ & $182,72 \pm 1,95$ & $1,19^{\mathrm{A}} \pm 54,65$ & $2,22^{\mathrm{A}} \pm 54,81$ \\
\hline
\end{tabular}

Ket ABC : Superskrip yang berbeda pada kolom yang sama menunjukkan perbedaan yang sangat nyata.

\section{Konsumsi Bahan Kering}

Tabel 2 menunjukkan konsumsi bahan kering pakan tertinggi terdapat pada perlakuan P0( Hijauan 100\% ) sebesar 477,34 dan konsumsi pakan tertinggi pada P2 (pelet 100\%) Sebesar 256,77 g/ekor/hari. Hal ini dipengaruhi oleh beberapa hal diantaranya : 1) Faktor pakan, meliputi daya cerna dan palatabilitas dan 2) faktor ternak yang meliputi bangsa, jenis kelamin, umur dan kondisi kesehatan ternak Lubis (1992). Hal ini juga sesuai dengan pendapat Parakkasi (1995) yang juga menyatakan bahwa palatabilitas pakan merupakan salah satu faktor yang mempengaruhi jumlah konsumsi pakan.

Menurut Kartadisastra (1997) bahwa palatabilitas dicerminkan oleh organoleptiknya seperti penampilan, bau, rasa, dan teksturnya. Penampilan pakan komplit daun ubi klon berbentuk pelet ini berwarna coklat, bau tidak terlalu manis, rasa asin. Pakan komplit daun ubi kayu berbentuk pelet tidak merubah kenampakan, bau rasa, dan tekstur dari pakan pelet lainnya. Menurut Kartadisastra (1997), keadaan fisik dan kimiawi pakan ditunjukkan oleh penampilan, bau, rasa, dan tekstur menumbuhkan daya tarik dan merangsang ternak untuk mengkonsumsinya. Konsumsi bahan kering biasanya dipengaruhi terutama oleh ukuran tubuh, jumlah energi yang terkandung dalam pakan dan laju pencernaan (Kearl,1982). Hal ini juga 
sesuai dengan pernyataan Kardisastra (1997), palatabilitas pakan, kadar protein kasar dan perlakuan pakan akan berpengaruh terhadap konsumsi bahan kering ternak ruminansia.

\section{Konsumsi Bahan Organik}

Berdasarkan Tabel 2 dapat dilihat konsumsi bahan organik pakan pada domba jantan lokal pada perlakuan P0 302,55 g/ekor/hari, P1 sebesar 318,10 g/ekor/hari dan P2 sebesar 182,72 g/ekor/hari. Jumlah konsumsi bahan kering akan berpengaruh terhadap konsumsi bahan organik, semakin meningkat konsumsi bahan kering maka konsumsi bahan organik juga juga meningkat dan sebaliknya (Kamal, 1994). Konsumsi bahan organik berkorelasi positif dengan konsumsi bahan kering, hal ini disebabkan karena zat-zat yang terkandung dalam bahan organik terdapat pula pada bahan kering. Menurut Tillman et al., (1998), bahan kering terdiri dari bahan organik dan anorganik, di dalam bahan organik itu sendiri terkandung lemak kasar, protein kasar, serat kasar, dan BETN, sedangkan bahan organik terdiri dari abu.

\section{Kecernaan Bahan Kering}

Hasil penelitian menunjukkan bahwa rataan kecernaan bahan kering (KcBK) masingmasing perlakuan adalah $47,00 \% \pm 3,34(\mathrm{P} 0), 52,43 \% \pm 1,38$ (P1) dan 54,65\% $\pm 1,19$ (P2). Hasil penelitian menunjukkan bahwa kecernaan bahan kering paling tinggi terdapat pada $\mathrm{P} 2(54,65 \% \pm$ 1,19) dan kecernaan bahan kering terendah pada P0 $(47,00 \% \pm 3,34)$. Kecernaan yang mempunyai nilai tinggi mencerminkan besarnya sumbangan nutrien tertentu pada ternak. Sementara itu pakan yang mempunyai kecernaan rendah menunjukkan bahwa pakan tersebut kurang mampu menyuplai nutrien untuk hidup pokok maupun untuk tujuan produksi ternak (Yusmadi et al., 2008).

Berdasarkan Tabel 2, hasil analisis ragam menunjukkan bahwa pakan komplit hasil samping ubi kayu klon memberikan pengaruh sangat nyata terhadap kecernaan bahan kering domba lokal jantan lepas sapih, hal ini disebabkan oleh pakan komplit hasil samping ubi kayu klon berbentuk pelet yang diberikan kepada ternak domba memiliki kandungan nutrisi yang lengkap, sehingga dapat meningkatkan daya cerna pakan itu sendiri dan yang mempengaruhi daya cerna tersebut adalah komposisi pakan. Hal ini sesuai dengan pernyataan Tilman et al., 
(1998) yang menyatakan bahwa yang mempengaruhi daya cerna adalah konsumsi pakan dan pakan dengan kandungan nutrisi yang lengkap akan meningkatkan daya cerna pakan itu sendiri.

Berdasarkan uji lanjut BNJ menunjukkan bahwa kecernaan bahan kering pada perlakuan P0 berbeda sangat nyata dengan perlakuan P1 dan P2. Hal ini dikarenakan tingkat kecernaan bahan kering dapat dipengaruhi oleh konsumsi ransum perlakuan dan komposisi kimia ransum perlakuan. Hal ini sesuai dengan pendapat Anggorodi (1990) faktor yang berpengaruh terhadap daya cerna diantaranya adalah bentuk fisik pakan, komposisi ransum, suhu, laju perjalanan melalui alat pencernaan dan pengaruh terhadap perbandingan nutrien lainnya. Pada perlakuan P1 dan P2 terlihat bahwa perlakuan tidak berbeda nyata atau berada dalam kelompok notasi yang sama . Hal ini sesuai dengan pernyataan Sutardi (1980) perbedaan sumbangan nutrien tertentu mempengaruhi daya cerna pakan pada ternak.

Nilai koefisien kecernaan bahan kering pakan pada penelitian ini dapat dikatakan sedang karena nilai koefisiennya diantara 47,00\%-54,65\% dengan rataan 51,36\%. Hal ini sesuai dengan pernyataan (Sutardi et al., 1983), yang menyatakan bahwa tingkat kecernaan akan menentukan seberapa besar gizi yang terkandung dalam bahan pakan secara potensial dapat dimanfaatkan untuk produksi ternak. Hasil penelitian yang menunjukan perbedaan yang sangat nyata pada kecernaan bahan kering antar perlakuan disebabkan karena perbedaan kandungan nutrisi pada perlakuan dengan pemberian hijauan dengan pemberian pelet. Dari hasil penelitian terlihat dengan pemberian pelet meningkatkan tingkat kecernaan bahan kering. Hal ini diduga karena kualitas pakan pada pelet lebih baik dalam meningkatkan jumlah mikroba rumen sehingga pakan yang dikonsumsi memiliki nilai kecernaan yang lebih baik. Bamualim (1988) menyatakan bahwa protein merupakan suatu zat makanan yang essensial bagi tubuh ternak dan tersedianya protein yang cukup menyebabkan aktivitas dan pertumbuhan mikroorganisme meningkat sehingga proses pencernaan dan konsumsi juga meningkat

\section{Kecernaan Bahan Organik}

Menurut Sutardi (1980), nilai kecernaan bahan organik dari suatu pakan dapat menentukan kualitas pakan tersebut. Berdasarkan Tabel 2 dapat dilihat rataan kecernaan bahan organik feses pada domba jantan lokal adalah P0 sebesar 50,19, P1 sebesar 52,74 dan P2 sebesar $54,81 \%$. 
Berdasarkan Tabel 2, hasil analisis ragam menunjukkan bahwa pakan yang diberikan pada domba jantan lepas sapi penelitian tersebut cukup memberikan nilai nutrisi bagi pertumbuhan mikroorganisme rumen, terutama dalam sintesis protein tubuhnya,. Menurut (Van Soest, 1994) kemampuan mencerna bahan makanan ditentukan oleh beberapa faktor seperti jenis ternak, komposisi kimia makanan dan penyiapan makanan. Lebih lanjut dijelaskan bahwa daya cerna suatau bahan makanan atau ransum tergantung pada keserasian zat-zat makanan yang terkandung didalamnya.

KcBO pakan merupakan persentase dari protein, lemak, vitamin dan karbohidrat yang dicerna selama proses pencernaan. Komponen bahan organik dalam sel tumbuhan sebagian besar adalah karbohidrat yaitu sebesar 50-70\% dari jumlah bahan kering (Tillman et al., 1998).Tinggi rendahnya KcBO pakan dapat menggambarkan ketersediaan energi yang dapat dimanfaatkan untuk ternak.

Berdasarkan uji lanjut BNJ menunjukkan bahwa kecernaan bahan organik pada perlakuan P0 berbeda sangat nyata dengan perlakuaan P1 dan P2 . Pada perlakuan P1 dan P2 terlihat bahwa perlakuan tidak berbeda nyata atau berada dalam kelompok notasi yang sama. Hal ini diduga karena mengikuti tingkat kecernaan bahan kering yang disebabkan oleh kandungan pada pellet baik untuk perkembangbiakan mikroba rumen sehingga meningkatkan tingkat kecernaan dari ternaknya. KcBK eratk kaitannya dengan KcBO karena sebagian besar bahan kering terdiri dari bahan organic, perbedaan keduanya terletak padda kadar abunya. Pernyataan ini diperkuat oleh Sutardi (1980) yaitu, bahan pakan yang memiliki kandungan nutrien yang sama memungkinkan KcBO mengikuti KcBK.

Protein yang cukup menyebabkan aktivitas dan pertumbuhan mikroorganisme meningkat sehingga proses pencernaan dan konsumsi juga meningkat. Lebih lanjut Oktarina et al., (2004) menyatakan bahwa peningkatan kadar protein dalam pakan akan meningkatkan laju perkembangbiakan dan populasi mikrobia rumen sehingga kemampuan mencerna pakan menjadi lebih besar. 


\section{KESIMPULAN}

Kesimpulan penelitian menunjukkan bahwa pemberian pakan hasil samping ubi kayu pada ternak domba memiliki tingkat kecernaan bahan kering dan bahan organik yang lebih tinggi dibandingkan dengan rumput.

\section{DAFTAR PUSTAKA}

Anggorodi, R. 1990. Ilmu Makanan Ternak Umum. Gramedia, Jakarta.

Bamualim, 1988. Pencernaan Mikrobia pada Ruminansia. Terjemahan Retno Muwarni. Gadjah Mada University Press. Yogyakarta.

Harris LE. 1970. Nutrition Research Technique for Domestic and Wild Animal. Vol 1. An Interna - tional Record System and Procedur for Analy - zing Sample. Animal Science Department. Utah State University. Logan.

Kamal, M. 1994. Nutrisi Ternak 1. Laboratorium Makanan Ternak. Jurusan Nutrisi dan Makanan Ternak. Fakultas Peternakan. Universitas Gajah Mada. Yogyakarta.

Kartadisastra, H.R., 1997. Penyediaan dan Pengelolaan Pakan Ternak Ruminansia (Sapi, Kerbau, Domba, Kambing). Kanisius, Yogyakarta.

Kearl, L.C. 1982. Nutrien Requirements of Ruminants in Develoving Countries. International Fedstufs Instiute. Utah Agricultural experiment station. Utah State University Logan. Utah USA.

Laboratorium Ilmu Makanan Ternak, Program Studi Peternakan FP USU Medan (2009).

Lubis, D. A. 1992. Ilmu Makanan Ternak, Pembangunan. Jakarta.

Mc.Donald, P., R. A. Edwards and J. F. D. Greenhalgh. 1995. Animal Nutrition. Foutrh Edition. Copublished in The United States with John Wiley and Sons, Inc. New York.

Oktarina, S. Chuzaemi dan Mashudi. 2004. Ilmu Gizi Ruminansia. Animal Husbandary Project, Universitas Brawijaya, Malang.

Parakkasi, A. 1995. Ilmu Nutrisi Makanan Ternak Ruminansia. UI Press. Jakarta.

Sutardi, T. 1980. Landasan Ilmu Nutrisi. Jilid 1. Ilmu Nutrisi dan Makanan Ternak. Fakultas Peternakan. IPB. Bogor.

Sutardi, T., N. A. Sigit dan T. Toharmat. 1983. Standarisasi Mutu Protein Bahan Makanan Ternak Ruminansia, Berdasarkan Parameter Metabolismenya oleh Mikrobia Rumen. Proyek Pengembangan Ilmu dan Teknologi. Ditjen Pendidikan Tinggi, Jakarta. 
Tillman, A.D, H. Hartadi, S. Reksohadiprodjo, S. Prawirokusumo dan S. Lebdosoekojo., 1998. Ilmu Makanan Ternak Dasar. Gadjah Mada University Press, Yogyakarta.

Van Soest, P. J. 1994. Nutritional Ecology of The Ruminant. 2nd Ed. Comstock Publishing Associates a Division of Cornell University Press, Ithaca and London.

Yusmadi. 2008. Kajian mutu dan palatabilitas silase dan hay ransum komplit berbasis sampah organik primer pada kambing PE. Tesis. Program Pascasarjana, Institut Pertanian Bogor, Bogor. 